\title{
Subject and Citizen: The Ambiguities of the Political Self in Early Modern England
}

Sujet et citoyen : les ambiguités du corps politique dans l'Angleterre de la première modernité

Luc Borot

\section{OpenEdition}

\section{Journals}

Electronic version

URL: http://journals.openedition.org/rfcb/735

DOI: $10.4000 / \mathrm{rfcb} .735$

ISSN: 2429-4373

Publisher

CRECIB - Centre de recherche et d'études en civilisation britannique

Electronic reference

Luc Borot, «Subject and Citizen: The Ambiguities of the Political Self in Early Modern England », Revue Française de Civilisation Britannique [Online], XXI-1 | 2016, Online since 20 July 2016, connection on 19 April 2019. URL : http://journals.openedition.org/rfcb/735 ; DOI : 10.4000/rfcb.735

This text was automatically generated on 19 April 2019

\section{c) (i) $\Theta$}

Revue française de civilisation britannique est mis à disposition selon les termes de la licence Creative Commons Attribution - Pas d'Utilisation Commerciale - Pas de Modification 4.0 International. 


\title{
Subject and Citizen: The
} Ambiguities of the Political Self in Early Modern England

\author{
Sujet et citoyen : les ambiguités du corps politique dans l'Angleterre de la \\ première modernité
}

Luc Borot

\section{Introduction}

1 Of two words in this title, one, 'citizen', is anachronistic in the modern, political sense. To refer to a member of the community living in the same kingdom, the term in use in early modern England would have been the other: 'subject'. 'Citizen' would have referred to an inhabitant of a city, who was also a member of the city's corporation. In some, he would have been called a 'freeman', as in the City of London. This anachronistic term is introduced to highlight a tension, which at times may have been close to contradiction, in the social and political minds and practices of early modern English people.

By law, all were the monarch's subjects, men and women alike. But political rights, or rather liberties (in the sense of privilege) would have belonged to males only. Charles I declared in his scaffold speech on 30 January 1649: "a subject and a monarch are clean different things", and subjects were not intended "for having share in government". ${ }^{1}$ Some of his subjects were indeed clearly in the process of ditching, as it were, the very notion of subjection for what they deemed to be the exercise of their freedom, in the idiom of classical republican ideas. Others, certainly more numerous, would rather have retained a monarchy, though with a more mixed constitution than what they had enjoyed or endured before the civil war.

3 The civic concepts of the republican ideology had not come out of the blue between the summer of 1648 and the winter of 1649 . Reluctance to deferential prerequisites could be spotted. As David Cressy showed in England on Edge, reluctance to deferential expectations 
could be spotted from the very beginning of the Long Parliament, with a climax of revolutionary potential in $1641 .^{2}$ But deep-rooted republican beliefs could also be traced back to civic and judicial practices, ideas and institutions already at work for several generations, and described in the Elizabethan age by such semi-official depictions of England as Sir Thomas Smith's De Republica Anglorum and William Harrison's Description of England. David Rollason, Paul Rahe and others in the past decade have tracked the beliefs concerning the commonweal(-th?) over 200 years. I have shown elsewhere some years ago, that the roles of courtier, counsellor and magistrate had been patterns of behaviour and career paths for gentlemen 'of the better sort' since the early Tudors, but how about the rest of the subjects? ${ }^{3}$

4 For others indeed, other patterns had come into being in the Elizabethan age, and in the 1640s radically new ones were being shaped, turning "Soldiers into Statesmen", in Austin Woolrych's phrase. Among the minority of activists that agitated the soldiery and the officer body of the New Model Army, it quickly became clear that the notion of 'subject' would have to be left by the roadside at some stage in the establishment of the government of the Saints, or of the people. Who the 'Saints' would be is a topic that will only be brushed past, as it were. Yet, in the pre-revolutionary kingdom or commonweal, several patterns of citizenship were available, that were fully compatible with the perpetuation of the monarchy.

5 To explain how such (to us) incompatible figures as those of the subject and the citizen could coexist, I shall first look at the language of nationality, monarchy and commonweal. I shall then consider, in their own terms, how some early modern English authors described the structure of participation in their society and 'constitution'. I shall end with a study of the polemical definitions that arose in the last years before the restoration of monarchy. ${ }^{4}$

\section{Nationality, kingdom and Commonweal}

6 As late in the civil war as October 1647, in the debates of the General Council of the Army held in Putney church, Oliver Cromwell and his son-in-law Henry Ireton called England a 'kingdom'. At that stage, very few political actors, if any, including these two gentlemen, were considering moving over to a republican regime. For just about a year, the Levellers had been developing a theory of legitimacy grounded in the people that can be considered as one of the first formulations of popular sovereignty. But this was not a definition of the people held by the majority of the English at the time.

7 If we look at the formulation of civic participation held by such men as Cromwell and Ireton, they drew a line between the natives of the realm in general, on the one hand, and on the other, those among the natives who held a permanent vested interest in the kingdom. The other natives were to be dealt with as aliens would be, i.e. with the right to the protection of life and limb, and the liberty of moving about. This quotation from one of Ireton's most famous speeches during the debates of 29 October, 1647, is unduly long, but it will be a constant point of reference throughout this paper. Part of the task in hand in this paper is to reconstruct a part of the mental structure that underpins this sort of statement.

I think that no person hath a right to an interest or share in the disposing of the affairs of the kingdom, and in determining or choosing those that shall determine what laws we shall be ruled by here-no person hath a right to this, that hath not a 
permanent fixed interest in this kingdom, and those persons together are properly the represented of this kingdom, and consequently are [also] to make up the representers of this kingdom, who taken together do comprehend whatsoever is of real or permanent interest in the kingdom. And I am sure otherwise I cannot tell what any man can say why a foreigner coming in amongst us-or as many as will coming in amongst us, or by force or otherwise settling themselves here, or at least by our permission having a being here-why they should not as well lay claim to it as any other. We talk of birthright. Truly [by] birthright there is thus much claim. Men may justly have by birthright, by their very being born in England, that we should not seclude them out of England, that we should not refuse to give them air and place and ground, and the freedom of the highways and other things, to live amongst us-not any man that is born here, though by his birth there come nothing at all (that is part of the permanent interest of this kingdom) to him. That I think is due to a man by birth. But that by a man's being born here he shall have a share in that power that shall dispose of the lands here, and of all things here, I do not think it a sufficient ground. ${ }^{5}$

8 One century later, William Blackstone, in his Analysis of the Laws of England, called "the absolute rights, or civil liberties", defined as "the right of personal security, or personal liberty, and of private property". ${ }^{6}$ At Putney, that was what Ireton famously allowed in his minimal definition of the birthright of any man "though by his birth there come nothing at all (that is part of the permanent interest of this kingdom) to him", as just quoted.

Blackstone is quoted here, though he was synthesising the principles of English law over a century after the events we are concerned with, because he tried to establish the most fundamental principles on which lawyers, over generations, had created some consensus. This is the way he defined the difference between aliens and natives:

1. The people are either aliens, that is, born out of the dominions, or allegiance, of the Crown of Great Britain, or natives, that is, born within it.

2. Allegiance is the duty of all subjects, being the reciprocal tie of the people to the prince, in return for the protection he affords them, and in natives, this duty of allegiance is natural and perpetual, in aliens is local and temporary only.

3. The rights of natives are also natural and perpetual, those of aliens local and temporary only, unless they be made denizens by the king, or naturalised by Parliament. $^{7}$

10 To look at other ways of defining the notions discussed, the OED, quoting various sources, defines the word 'denizen' as:

By restriction: One who lives habitually in a country but is not a native-born citizen; a foreigner admitted to residence and certain rights in a country; in the law of Great Britain, an alien admitted to citizenship by royal letters patent, but incapable of inheriting, or holding any public office.

11 Aliens and natives alike owe allegiance to the sovereign, perpetually if natives, for a time only if aliens. They owe allegiance in return for the protection of their rights, but owe duty to the king. Blackstone does not say anything about civic commitments of the kind vindicated by the soldiers of the New Model Army and the Levellers. He is not a political thinker, but a lawyer, a legal thinker describing the legal system.

Both Elizabeth I and James VI \& I believed in the patriarchal nature of their kingly office. Patria potestas endowed monarchs with the power of life and death over their subjects, according to principles inherited from Roman civil law. Lands, goods and chattels belonged to them, and lands were owned through them as tenures. ${ }^{8}$ That such an ideology should have been formulated as late as the 1590 s by the then king of Scotland, shows that 
the theory of absolute monarchy was clashing with the real self-representations of the members of the societies of England and Scotland.

The extreme formulations repeatedly proffered by James in his capacities as king of Scotland or England can be read as rhetorical hyperboles of some kind: by stating them in treatises or in speeches to Parliament, he could persuade himself of the extent of his office, and by overstating his power to his subjects in Parliament, who were aware that they were not 'mere subjects', he hoped to apply some degree of pressure on them to comply with his will. Experience shows that they maintained a high opinion of their privileges and liberties as members of the Parliament of England, in spite of the ideology that the king was trying to convey to them. His predecessor had indeed experienced their constancy in confronting the Crown throughout her reign.

There was no such thing as a centralised, effective, efficient royal administration in England at the beginning of the 17th century, nor for quite some time after. ${ }^{9}$ Under Queen Elizabeth, the established Church had begun to extend its presence to the whole territory, but it was still, and for some time, the only institution to manage a kingdom-wide network with a single-minded purpose to back it. The other, older, national network, but that did not reach out to every parish and hamlet, was the judiciary. The circuits, the circuit judges, the 'Quorum' of the county Justices of Peace appointed from the local gentry by the Lord Chancellor, were the closest to a centralised top-down secular administration that one could get.

At a lower territorial level, such local judicial institutions as the parish- or manor-courts, with their juries of freeholders, were the first port of call for subjects in need of redress in civil or criminal cases. Being a juror at the manorial court was a duty of the freeholders connected to their very tenure, in the feudal tradition, like mending a bridge or trimming a certain hedge adjacent to their land. Such jurors' incomes may have been below the $40 \mathrm{~s}$ . value required from voters for the selection of the members of the House of Commons.

Under the Poor Laws, welfare relief was distributed by parish-elected Overseers of the Poor, and the rates from which they were funded were levied by the same officers. It was required of the Overseers that they should conform to the established religion of the realm, and they apparently did, to a man... or to a woman. Indeed, there were two areas in which there is evidence of female administration: as churchwardens they could take part in the management and discipline of church-life in the community, and as Overseers of the Poor, they could participate in the collection and distribution of alms. ${ }^{10}$

In those days of slow communication, low literacy rate, and expected social deference, knowing one's standing in the world was essential (whether in terms of gender, age or degree), but not pretending to an office not befitting one's standing was no less crucial, in principle at least. This was a tradition-minded and antiquity-ridden culture in many ways, in principle or for the public eye at least. Indeed, in many law-cases, the immemorialness argument was crucial for the judges to pronounce a ruling. But from our modern vantage point, let us not overlook what it meant: "time out of memory' meant 'time out of memory of man alive". In an age of low life-expectancy, in which leases were granted for one life or 33 years, two lives or 66 years, three lives or 99 years, length of local human memory could be short indeed, and span no more than three quarters of a century. ${ }^{11}$

By way of consequence, this was very much an innovation-fearing society, as the revisionist historians have kept reminding us since the mid-1970s, not without good 
reason. Yet, the spirit of innovation and invention displayed in England from the mid-1640s onward cannot have sprung out of a vacuum. Can the word and notion of 'commonwealth' have emerged from the Rump members' minds in the aftermath of the king's trial and execution? In no way indeed!

The web of local and national institutions involving people at various levels in the management of the kingdom was one of the things meant by the words 'commonwealth' or 'commonweal', in the early modern age. Though this distinction is artificial, this nexus of relations will be referred to here by the latter word, 'commonweal', to avoid confusion with the republican regime of the 'godly sort', but we must remain aware that to contemporaries, there was no such distinction. Polysemy was the rule: lack of a firm definition of the term made it possible to use it in many rhetorical and ideological contexts..$^{12}$ The idea that the commonweal's welfare was the object of the gentleman's dedication is obvious in such treatises as Sir Thomas Elyot's Book Called the Governor as early as $1531 . .^{13}$ There was indeed no top-down centralised machinery, but there was a web of local customs and duties, and people who operated such offices. Such a web or network of institutional and personal relationships, binding its operatives together, and binding them ultimately to the Crown above them, and to the other subjects below them, is what they referred to as 'the commonweal'. It did involve horizontal, as well as vertical, connections between members of 'society', as we would probably call it today.

As can be understood from Ethan Shagan's work on popular politics under the early Tudors, the rebels of the Pilgrimage of Grace of 1536 not only rebelled against the changes in the religious society, life and beliefs consequent on the abolition of the chantries and religious orders, but also against what they saw as the new and corrupt way of ruling implemented by Henry VIII's advisers, which they could see as "the abandonment of good lordship", in Shagan's words. He sees the rebels as wanting to "reconstruct good lordship through the creation of a properly functioning socio-political order within the rebellion itself." ${ }^{14}$ With the anachronistic hindsight to which we are tempted by modernity, this traditionalist view might have clashed with Henry's decision to be supported throughout his reform of the Church by a sitting Parliament. Some social forces were indeed participating in the process of change, but by 1536 they might have been perceived by some of their fellow countrymen as part and parcel of the corrupt body of advisers that were economically benefiting from the sale of Church lands. This crisis illustrates the differing paces of change in social, political and constitutional visions, in different social strata and in different regions of early modern England.

Though it was often couched in the language of king-and-subject allegiance, there was a version of English civic culture that permeated the world-view of those involved in somehow managing the country at some level or other. This was what some Tudor authors described in their works as the Respublica Anglorum.

\section{De Republica Anglorum}

22 It has by now become useful to address the problem of defining, as far as it is rationally and reasonably possible, the semantic field covered by the translations of respublica in English. It is impossible to understand the business of the subject or citizen, unless the framework in which his activity was conducted is first defined. 

(financially), or interest. Respublica is the regime of the Roman republic, i.e., the institutions created at the fall of the monarchy. It is both a republican regime, and the State with its institutions, social and political. As publicus comes from populus, it involves the interest of the people, i.e. of the cives, the citizens of the republic. Populus, importantly for my purpose today, must be distinguished from plebs, viz. the inhabitants who are below the level of civis, citizen. This point was not missed by Sir Thomas Elyot, when he rejected the translation of respublica by 'commonweal' for, as this would in fact translate res plebeia, the interest of the plebs, of the common people, of the rabble, not of the people (populus), by whom he understood those who have an interest to care for. Hence his suggestion to translate respublica by "weal public": the good of the people, of those who own something that profits the kingdom..$^{15}$

Henry Ireton, in Putney church, on 29 October 1647, would call such men "those who have a permanent vested interest in the kingdom". To men who lived as far apart as 1530 and 1647, a citizen, as I propose to define it in an anachronistic thought experiment, was a native subject with an interest in the kingdom, the kind of interest that motivated, legitimated, justified, and to some extent required, that he should be active in the management of things (res) beyond his estate, no matter how small the things and how small the estate. The object of the discussion about franchise at Putney was the definition of the smallest common denominator, the smallest 'interest' making such an involvement a 'liberty' (i.e. a right by privilege) for an individual.

In the early 1580s, the diplomat Sir Thomas Smith had described the realm and commonwealth of England for the benefit of foreigners in his De Republica Anglorum, first published in 1583, subsequently revised and expanded, and repeatedly printed over forty years. In it, staying very close to Aristotle, he defined the 'common wealth' as "a society or common doing of a multitude of free men collected together and united by common accord and covenants among themselves, for the conservation of themselves as well in peace as war" ${ }^{16}$ Before that, the same author had defined the king as:

Where one person bears the rule they define a king, who by succession or election cometh with the good will of the people to that government, and doth administer the common wealth by the laws of the same and equity, and doth seek the profit of the people as much as his own. ${ }^{17}$

It would appear by this definition that the commonweal predates the king: the members' mutual covenants constitute them as a people. Later, Locke would agree with this presentation, not so Hobbes.

In chapter 26, about "the division of the parts and persons of the common wealth", Smith says that freemen must be defined:

as subjects and citizens of the commonwealth, not bondmen who can bear no rule nor jurisdiction over freemen, as they who be taken but as instruments and of the goods and possessions of others. ${ }^{18}$

The following chapters define the nobilitas maior, who sit in the upper House of Parliament, the esquires and gentlemen who are the nobilitas minor (i.e. the gentry), and in chapter 22 the burgesses and citizens, "such as not only be free and received as officers within the cities, but also be of some substance to bear the charges". ${ }^{19}$ In counties they are of no power, but they may take part in the law-making process as members of Parliament. But the most interesting chapter, and the most relevant to the matter in hand, is chapter 23 , on yeomen, which focuses on the freemen as the backbone of the nation, the heirs to the 
archers and foot soldiers of yore who won the English kings' battles on French soil. You can expect Ireton to have read this description or others of the same sort. Smith writes:

Those whom we call yeomen next unto the nobility, the knights and squires, have the greatest charge and doings in the commonwealth, or rather are more travailed to serve in it than all the rest [...]. I call him a yeoman whom our laws call legalem hominem, a word familiar to writs and inquests, which is a freeman born English, who may dispend of his own free land in yearly revenue to the sum of $40 \mathrm{~s}$. sterling by the year. This makes [in 1583 money value] $£ 6$ [...]. This sort of people confess themselves to be no gentlemen, but give honour to all which be or take upon them to be gentlemen, and yet they have a certain pre-eminence and more estimation than labourers and artificers, and commonly live wealthily, keep good houses, do their business and travail to get riches [...]..$^{20}$

A hint that social mobility, which was officially frowned upon, was a fact of life in Elizabethan society, and later to be sure. By dint of work, trade, husbandry and investment in their sons' education, these not so humble yeomen turn their sons into gentlemen:

These [yeomen] be (for the most part) farmers to gentlemen, and with grazing, frequenting of markets, and keeping servants, not idle servants as the gentleman doth, but such as get both their own living and part of their masters: by these means do come to such wealth, that they are able and daily do buy the lands of unthrifty gentlemen, and after setting their sons to the schools, to the universities, to the law of the realm, or otherwise leaving them sufficient lands whereon they may live without labour, do make their sons by those means gentlemen. ${ }^{21}$

In the Elizabethan era, parishioners heard from the pulpit the parts of the books of Homilies that preached obedience, deference and social stability as being the will of God.

Everie degree of people in their vocation, calling and office, hath appointed to them their duety and order: some are in high degree, some in low, some Kings and Princes, some inferiors and subjects, Priests and lay-men, Maisters and Servaunts, Fathers, and Children, Husbandes and Wives, riche and poore, and every one have neede of other, so that in all things is to bee lauded and praysed the goodlie order of God, without the which, no house, no Citye, no commonwealth can continue and endure or last. ${ }^{22}$

31 Meanwhile the gentlemen anatomists of the realm and commonweal of England were describing upward and downward social mobility as a matter of fact, as the last quote shows. Likewise, in chapter 20 "Of Gentlemen", Smith ambiguously describes the way Englishmen could become gentlemen, with an oft-quoted quip: "for as gentlemen, they are made good cheap in England", but more seriously, he explains that kings only make knights and barons, whereas the commonwealth can acknowledge the gentry status of certain persons, which is made official through the generous (indeed corrupt) agency of the King of Heralds, the court officer entitled to grant new coats of arms.

[F]or as gentlemen, they are made good cheap in England. For whosoever studies the laws of the realm, who studies in the universities, who professes liberal sciences, and to be short, who can live idly and without manual labour, and will bear the port, charge and countenance of a gentleman, he shall be called master, for that is the title which men give to esquires and other gentlemen, and shall be taken for a gentleman. [...] (and if need be) a king of Heralds shall also give him for money, arms newly made and invented, which the title shall bear that the said Herald has perused and seen old registers where his ancestors in times past had born the same. ${ }^{23}$ challenged by men of all ranks between the spring of 1640 and that of 1642 , there is ample 
evidence that the awareness of social mobility, and therefore of the uncertainty of status, was a common concern of social anatomists, as early as the Elizabethan era. The weight of the unspoken or of the socially unspeakable was on everyone, but such awareness is likely to have been present across a wide spectrum of the commonweal, not least among those who had a permanent vested interest in denying it, or in having it publicly denied.

From the estate of yeomanry must have come an important section of the soldiery of the New Model Army indeed, whose anxieties are voiced in Putney as in several pamphlets: a freeman who ventured his life and goods in the war for the Parliament-men against the king, and is not worth $40 \mathrm{~s}$. anymore, has lost even the political rights that were his by birth or achievement, hence the Levellers' insistence on widening the definition of the concept of birthright, and Ireton's interest in narrowing its relevance to the political challenge he was confronted with. ${ }^{24}$

But Smith also includes in the commonwealth those 'which do not rule', in chapter 24: "day labourers, poor husbandmen, yea merchants or retailers which have no free land, copyholders, all artificers, as tailors, shoemakers, carpenters, brickmakers, bricklayers, masons, etc....". Yet, they are not left without participation in the administration of government in the commonweal:

These have no voice nor authority in our common wealth, and no account is made of them but only to be ruled, not to rule other, and yet they be not altogether neglected. For in cities and corporate towns for default of yeomen, they are fain to make their inquests of such manner of people. And in villages they be commonly made churchwardens, aleconners, and many times constables, which office toucheth more the common wealth, and at the first was not employed upon such low and base persons. ${ }^{25}$

Carl Bridenbaugh, in Vexed and Troubled Englishmen, revealed that some petty constables were chosen in spite of their illiteracy, which was a severe problem in the discharge of their duties. ${ }^{26}$ Indeed, such were the men that Ireton and other Army leaders of the same faith and estate meant to maintain out of the civic body, as not being 'free men', in all the senses that we have seen before. Yet, in the struggles of the many-faced and manyheaded opposition to the king's prerogative, a multitude of 'such low and base persons' involved themselves and reached considerable influence among their peers in their regiments, as outside the New Model. As Michael Mendle has shown, their real or imagined social and economic sameness was never synonymous with a clear unity of interpretation of who the people (and even the nation) were (or was). ${ }^{27}$ Smith's very broad and inclusive definition may have provided reasons for inclusiveness in the minds of some agents of the regiments at Putney, but on the other hand, it also made the social differences explicitly distinctive.

\section{Saint, Militant, or Citizen?}

I am deliberately using anachronistic descriptors for what I called 'intervention' in an earlier piece of work. When no legal, constitutional participation is possible, then you are left with various modes of intervention. In a paper in French political lexicology, I once criticised the use of the word 'citoyen' as an adjective concealing militant conceptions of activism and citizenship, as different from, or even superior to passive citizens content with casting a ballot every now and then. ${ }^{28}$ I now tend to use the same epithet-noun for what I am describing: to men who had lost their social status, or who had none in the 
mental world of Sir Thomas Elyot, Sir Thomas Smith or Henry Ireton, the spectacular utterance of their religious or political views in a dramatic setting must have been a far loftier human duty than merely casting a ballot. As Claire Gheerardt-Graffeuille has shown, this could also apply to women; it should also be pointed out that this applies, whether or not their menfolk -fathers or husbands- belonged to the politically able part of the commonweal. ${ }^{29}$

Pretending to divine inspiration, like the outcast Gerrard Winstanley in his prophetical pamphlets, acting prophetically like the Quakers George Fox or James Naylor, imitating the patterns of behaviour of the Marian Martyrs like the gentleman, soldier and writer John Lilburne, were so many forms of intervention for people who were, of had become, outcasts, or found it worth their while to pose as such. ${ }^{30}$ The Old Testament prophets were patterns of behaviour, as were the Marian martyrs, and like them they were patterns of disobedience to godless or Anti-Christian tyranny. Being under God's law removed them from the authority of human laws. For such people, being a subject was irrelevant: the transcendent nature of their message that came from the highest of highest put them beyond the pale, though not beyond the reach, of any sovereign who might pretend to absolute power and expect utter submission. Above the laws of man, beyond the authority of tyrants, they could not be reconciled with the humdrum view of deferential society, but they may also believe that they were beyond the world of the republican vivere civile, hence a further questioning of their political positioning: could they ever be good, quiet, republican citizens? Yet, at the Restoration, before converting to Quakerism and dying in that faith, Winstanley was a conforming Anglican, though for a short while only. ${ }^{31}$

Still, for those who did not experience the prophetic calling, but were merely promoting the rights of their fellow-citizens who neither could nor would look on themselves as subjects, a form of political immanence had performed the office of transcendent inspiration for the others. Promoting the sovereignty of the subjects implied erasing the mystique of political theology. Most of the very godly Levellers who advocated what we now call popular sovereignty must have been persuaded that "there is no power but of God", in Paul's famous words in Romans XIII, but they must have understood it as a form of divine-right popular sovereignty. As Harrington depicted a divine-right republic of the Hebrews, as the monarchomachs had theorised a divine right of the intermediate magistrates to lead the sanior sanctiorque pars reipublicae into a tyrannicidal rebellion, it is possible to imagine the blessed remnant of the defeated Leveller soldiers after the repression of the Burford rising in April 1649, pondering the defeat of the chosen people of God. Not the God who predestined men to subjection, but the One who liberated the captive Israelites from Egyptian bondage. This is the mood that Christopher Hill described, in one of his most reflectively perceptive books, as "the experience of defeat".

The sort of active citizenry outlined by the Cromwellian constitutions, the "Instrument of Government" of 1653 and the "Humble Petition and Advice" of 1658 fail to meet the criteria of prophecy and of universal citizenship. The property qualifications they defined were extremely high, and the confessional and ideological criteria that were added to them pointed to a narrow wedge of the parliamentary godly sort. Sir Thomas Smith would have been hard pressed to recognise in this bulwark of militant Puritanism the bustling Elizabethan society he had depicted seventy years before. Indeed, the first of these constitutions defined the ideological and confessional criteria first (such as the exclusion of whoever sided with the king and never turned to Parliament's side since 
January 1642, Catholics), and only then proceeded to the property qualifications (estates above the value of $£ 200$ per annum). The second document provides more details as to the exclusion criteria, adding the people who were involved in conspiracies against the Lord Protector and risings since 1653. A set of exclusions is added, concerning the people unfit to serve in Parliament: blasphemers, offenders against religion, Catholics or their spouses and children, Scripture denyers (which was aimed at the Quakers, among others), people known to profane the Sabbath, or to 'haunt' taverns. A committee was to be appointed to examine the morality of the members returned by the voters. ${ }^{32}$

If we are to accept the received estimation that the 'godly sort' were never more than 5\% to $10 \%$ of the English population, if we bear in mind that over the decade of civil wars and revolution many English households had seen their fortunes considerably decline, and that 14 years of godly rule had made a considerable part of the population impatient of their stratocratic and theocratic rulers, how many supporters could the regime still expect to support its fads? Confessional, ideological, and social, not to say financial support had inevitably shrunk over time. By the time of Cromwell's death, his regime was less popular than the king's at the peak of hostility by 1641-1642.

41 Aware of such a shortage of enthusiasts for the republican cause at home or abroad, two different schools of republican thought set out to work in the late 1650s. One was already at work before the death of Cromwell in September 1658, with James Harrington (never a supporter of Cromwellian rule) and his political associates; the other was working for the regime, with John Milton as its main penman. The minister Richard Baxter also put pen to paper to uphold the view of a holy commonwealth. To Harrington, all men who were not servants were citizens and formed the army of the commonwealth. It rested on a theory of the balance of property, within which upward and downward mobility made sure that the citizen body was extendable to whoever left servant status to become independent, or moved above or below the $£ 100$ mark that ensured membership of the senatorial body. Only atheists, Catholics and Jews were to be excluded from citizenship for religious reasons. ${ }^{33}$ To Milton, the commonwealth, in the spirit of the Cromwellian cause, could only be protected through the government of a nominated single-house parliament of godly men, preserving the spirit of the regime against the majority of the ungodly: only the godly had a divine right to rule, and the rest a duty to obey. ${ }^{34}$ To Baxter, the citizen body was to consist exclusively of men whose godliness was a testimony of their election. To him as to Milton, participation and government were the preserve of the Saints. His definition, though, was broader and more strictly religious than Milton's: to the Latin Secretary, ideological and military considerations came to colour, as it were, the soteriological aspects of divine election. ${ }^{35}$

of these three authors (but they were by no means isolated), only Harrington has the "expansion" of the commonwealth in view. The others are more concerned, or even obsessed, with the preservation of ideological purity, to the detriment of the support that the commonweal at large (i.e. society) could give to the commonwealth (i.e. the republican institutions), in the sense that was given to these terms at the beginning of this paper.

\section{Conclusion}

The debate on citizenship in early modern England is in many ways a discussion on inclusion and exclusion. It has been a well-established creed among historians of this period that the whole age could be defined as the growth of the nation-state, whose 
building bricks were the national Church, royal absolutism and the first seeds of parliamentary sovereignty. Looking at the processes at work from another angle, it may also appear as an age of struggle for social control (the godly $v$. the crown), as a fight between the 'commonweal' as society and the 'commonwealth' as State. While Smith called England a respublica, Hobbes wanted to define the commonwealth as civitas, whereby he did not mean a city-State of the Florentine or Venetian sort, but the modern, sovereign-centred State. One may consider this development as a step forward in political efficiency, but also as a loss of local control and self-administration. Hobbes's "civis" in his De Cive is a deliberately, consciously obedient subject whose civic duty consists in following commands to further the common peace and good. His commonwealth is not for citizens in the modern sense.

The utopian or normative definitions of citizenship of the later Interregnum look towards a medieval-like ideal of monastic perfection. It is a clear symptom of the cultural discrepancies and mental crises of the age, that the same 'Good Old Cause' could be advocated by authors like Milton and Baxter who wanted different kinds of 'the rule of the Saints', who coexisted with the classical republican idiom of tyrannicide as exemplified in Edward Sexby's Killing No Murder, calling for the holy murder of oliver Cromwell in 1657. The same minds, as Michael Mendle has explained about the Putney debaters, made their own spontaneous syntheses between their political and religious beliefs, their classical and biblical cultures. ${ }^{36}$ They emerged with absolute statements at a few months' distance, that seem contradictory to us, but were their means to make sense of the intellectual, social and political shambles of their days, and made sense at a given point in time in front of crises that no commonweal before had been confronted to, over such a brief period of time.

Luc Borot, ancien élève de l'ENS Ulm, membre honoraire de l'Institut Universitaire de France, est Professeur de civilisation britannique du XVIIe siècle à l'Université Paul-Valéry Montpellier. Il est membre de l'Institut de Recherche sur la Renaissance, l'Âge Classique et les Lumières (UMR $5186 \mathrm{du}$ CNRS). Son champ de recherche couvre l'histoire culturelle et l'histoire intellectuelle de l'Angleterre moderne, les rapports entre le politique et le religieux, les idées républicaines et proto-démocratiques. Il a dirigé la Maison Française d'Oxford de 2008 à 2012.

\section{BIBLIOGRAPHY}

Ayers, Robert (ed.) \& Austin Woolrych (intro.), The Complete Prose Works of John Milton, vol. 7, 1659-1660 (New Haven (CT), Yale UP, 1974).

Blackstone, William, An Analysis of the Laws of England, $5^{\text {th }}$ edition (Dublin, 1766).

Borot, Luc, "Conseiller, courtisan, citoyen: trois figures de la participation politique du sujet dans l'Angleterre moderne", in Luc Borot (ed.), Civisme et citoyenneté... une longue histoire (Montpellier, Publications de l'Université Paul-Valéry, 1999), pp. 92-141.

Borot, Luc, “L'adjectif 'citoyen”, Cités 3 (June 2000), pp. 231-235. 
Borot, Luc, "Richard Overton and radicalism: the new intertext of the civic ethos in mid seventeenth-century England", in Glenn Burgess, and Matthew Festenstein (eds), English Radicalism 1550-1850 (Cambridge, CUP, 2007), pp. 37-61.

Bradstock, Andrew (ed.), Winstanley and the Diggers, 1649-1999 (London \& Portland (OR), Franck Cass, 2000).

Bridenbaugh, Carl, Vexed and Troubled Englishmen (New York, OUP, 1976).

Calthrope, Charles, The Relation between a Lord of the Manor and the Copy-Holder his Tenant (1635).

Certaine Sermons Appointed by the Queenes Maiestie, to be declared and read... (London, 1587).

Cressy, David, England on Edge. Crisis and Revolution 1640-1642 (Oxford, OUP, 2006).

Damrosch, Leopold, The Sorrows of the Quaker Jesus. James Nayler and the Puritan Crackdown on the Free Spirit (Cambridge (MA) \& London, Harvard UP, 1996).

Early Modern Research Group, "Commonwealth: the Social, Cultural, and Conceptual Context of an Early Modern Keyword”, Historical Journal 54:3 (2011), pp. 659-687.

Elyot, Sir Thomas, The Book Named the Governor, S.E. Lehmberg (ed.), Everyman's Library n ${ }^{\circ} 227$ (London, Dent, 1962).

Firth, C.H. (ed.), The Clarke Papers (1891-94) (London, Royal Historical Society, 1992).

Gheerardt-Graffeuille, Claire, La Cuisine et le forum. L'émergence des femmes sur la scène publique pendant la Révolution anglaise (1640-1660) (Paris, L'Harmattan, coll. Des Idées et des femmes, 2005).

Gurney, John, Brave Community. The Digger Movement in the English Revolution (Manchester, Manchester UP, 2007).

Hill, Christopher, The Experience of Defeat. Milton and Some Contemporaries (London, Peregrine Books, 1985).

Kenyon, J.P. (ed.), The Stuart Constitution. Documents and Commentary (Cambridge, CUP, 1966).

Lamont, William (ed.), Richard Baxter, A Holy Commonwealth (1659), Cambridge Texts in the History of Political Thought (Cambridge, CUP, 1994).

Lockyer, Roger (ed.), The Trial of Charles I (London, the Folio Society, 1959).

Mendle, Michael, "Putney's pronouns: Identity and indemnity in the Great Debate", in Michael Mendle (ed.), The Putney Debates of 1647 - The Army, the Levellers and the English State (Cambridge, CUP, 2010), pp. 125-147.

Pocock, J.G.A. (ed.), The Political Works of James Harrington (Cambridge, CUP, 1977).

Shagan, Ethan, Popular Politics and the English Reformation (Cambridge, CUP, 2003).

Sharpe, Andrew (ed.), The English Levellers, Cambridge Texts in the History of Political Thought (Cambridge, CUP, 1998).

Smith, Sir Thomas, De Republica Anglorum (Mary Dewar, ed.) (Cambridge, CUP, 1982).

\section{NOTES}

1. Roger Lockyer (ed.), The Trial of Charles I (London, the Folio Society, 1959), p. 135.

2. David Cressy, England on Edge. Crisis and Revolution 1640-1642 (Oxford, OUP, 2006), pp. 6-24. 
3. Luc Borot, "Conseiller, courtisan, citoyen: trois figures de la participation politique du sujet dans l'Angleterre moderne" in Luc Borot (ed.), Civisme et citoyenneté... une longue histoire (Montpellier, Publications de l'Université Paul-Valéry, 1999), pp. 92-141; "Richard Overton and radicalism: the new intertext of the civic ethos in mid seventeenth-Century England" in Glenn Burgess and Matthew Festenstein (eds), English Radicalism 1550-1850 (Cambridge, CUP, 2007), pp. 37-61.

4. Before going further, I must acknowledge my debt to a collective paper published in 2011 in the Historical Journal: "Commonwealth: the Social, Cultural, and Conceptual Context of an Early Modern Keyword". I am applying some of the definitions and conclusions of that paper to my inquiry into the members of the commonweal who were also users of the word itself.

5. Henry Ireton, Putney Debates, 29 October 1647, in C.H. Firth (ed.), The Clarke Papers (London, Royal Historical Society, 1992 (1891-94)), p. 302.

6. William Blackstone, An Analysis of the Laws of England, $5^{\text {th }}$ edition (Dublin, 1766), Book I, ch. IV, section 8, p. 7.

7. Ibid., Book I, ch. XII, sections 1-3, p. 21.

8. Elizabeth I, Collected Works, vol. I, Leah Marcus, Janel Mueller, and Mary Beth Rose (eds), speech 23, 30 November 1601, pp. 337-9; James VI \& I, The Trew Law of Free Monarchies..., Bernard Bourdin (ed., trans.), Collection Astræa Texts $n^{\circ} 2$ (Montpellier, Presses Universitaires de la Méditerranée, 2008), pp. 30-32, pp. 54-58.

9. Under James I, the notion that specialised administrations ought to be developed emerged, but the first serious attempts to distribute ministerial departments date back to Cromwell and Charles II. It should be no surprise that such Harringtonian Commonwealthsmen as Sir William Petty, John Aubrey or Samuel Pepys should have been involved in this process after the Restoration of the Stuarts.

10. Carl Bridenbaugh, Vexed and Troubled Englishmen (New York, OUP, 1976), p. 248.

11. Charles Calthrope, The Relation between a Lord of the Manor and the Copy-Holder his Tenant, 1635, p. 50. According to Prescription Act 1832, legal memory, unless proof exists from the reign of Richard I, will be deemed to mean 30 or 60 years before the action at law, depending on the matter in hand. 2 and 3 Will 4 (1832) chapter 71, provision 1.

12. "Commonwealth...", pp. 661-62.

13. Sir Thomas Elyot, The Book Named the Governor, S.E. Lehmberg (ed.), Everyman's Library 227 (London, Dent, 1962).

14. Ethan Shagan, Popular Politics and the English Reformation (Cambridge, CUP, 2003), p. 95.

15. Elyot, Governor, pp. 1-2; Filmer, quoted in 'Commonwealth...', wants to keep 'commonwealth' for popular regimes, and 'commonweal' for the community, p. 667, n19.

16. Sir Thomas Smith, De Republica Anglorum, Mary Dewar (ed.) (Cambridge, CUP, 1982), ch. 10, p. 57.

17. Ibid., ch. 7, p. 53.

18. Ibid., ch. 16 , p. 64 .

19. Ibid., ch. 22 , p. 73.

20. Ibid., ch. 23, p. 74 .

21. Ibid., ch. 23 p. 74.

22. "An Exhortation concerning Good Order, and Obedience to Rulers and Magistrates", in Certaine Sermons Appointed by the Queenes Maiestie, to be declared and read... (London, 1587), sig. I3. This is an Elizabethan edition of the 1547 volume appointed by Henry VIII and mostly written by Cranmer.

23. Smith, ch. 20, pp. 71-2.

24. This is clear in the first and third versions of the "Agreement of the People", in Andrew Sharpe (ed.), The English Levellers, Cambridge Texts in the History of Political Thought (Cambridge, CUP, 1998), pp. 92-101, 168-178. 
25. Smith, ch. 21, pp. 76-77.

26. Bridenbaugh, pp. 250-51.

27. Michael Mendle, "Putney's pronouns: Identity and indemnity in the Great Debate" in Michael Mendle (ed.), The Putney Debates of 1647 - The Army, the Levellers and the English State (Cambridge, CUP, 2010), p. 134, p. 143, p. 146.

28. Luc Borot, “Conseiller, courtisan, citoyen”; "L'adjectif “citoyen”, Cités 3 (June 2000), pp. 231-235.

29. Claire Gheerardt-Graffeuille, La Cuisine et le forum. L'émergence des femmes sur la scène publique pendant la Révolution anglaise (1640-1660) (Paris, L'Harmattan, coll. Des Idées et des femmes, 2005).

30. Leopold Damrosch, The Sorrows of the Quaker Jesus. James Nayler and the Puritan Crackdown on the Free Spirit (Cambridge (MA) \& London, Harvard University Press, 1996).

31. John Gurney, Brave Community. The Digger Movement in the English Revolution (Manchester, Manchester UP, 2007), pp. 218-222; James D. Alsop, “Gerrard Winstanley: What do we know of his life?" in Andrew Bradstock (ed.), Winstanley and the Diggers, 1649-1999 (London \& Portland (OR), Franck Cass, 2000), pp. 30-33.

32. J.P. Kenyon (ed.), The Stuart Constitution. Documents and Commentary (Cambridge, CUP, 1966), p. 344, pp. 351-52.

33. James Harrington, The Commonwealth of Oceana (1656), in J.G.A. Pocock (ed.), The Political Works of James Harrington (Cambridge, CUP, 1976).

34. John Milton, The Ready and Easy Way to Establish a Free Commonwealth (1660), in Robert Ayers (ed.) \& Austin Woolrych (intro.), The Complete Prose Works of John Milton (vol. 7, 1659-1660) (New Haven (CT), Yale UP, 1974).

35. Richard Baxter, A Holy Commonwealth (1659), William Lamont (ed.), Cambridge Texts in the History of Political Thought (Cambridge, CUP, 1994).

36. Mendle, “Putney's pronouns”, p. 134.

\section{ABSTRACTS}

In 17th-century England, the notion of citizenship can only be understood by contradistinction with the definition of the subject. Englishmen of the time were aware that they were both subjects of the monarch and members of the common weal, defined as the web of relationships, privileges and obligations that got society and its institutions working, down to the most local levels of the parish or the manor.

Thus, some descriptions of English society and institutions in the late $16^{\text {th }}$ century revealed a point that was confirmed by the crises in collective identification that raged in the 1640s. The soldiers of the New Model Army disagreed together, as they also disagreed with their generals, such as Oliver Cromwell and Henry Ireton, on the definition of the people who was to be represented in Parliament. The Putney debates of the Autumn of 1647 reveal such mutual misunderstandings, as well as the underlying fears.

From 1653, the constitutions of the Cromwellian regime paint an increasingly detailed portrait of the active citizen, as they exclude some persons from the franchise for motives of personal morality or religious conformity, as well as economic reasons. As it raised the property qualifications and piling up conformity criteria, the regime keeps isolating itself from society. 
By the end of the 1650s, the struggle of the secular or religious republican theorists focuses on admission to citizenship, and on the size of the citizen body. Though they all agreed on the need for property qualifications, the polemic raged on the relevance of ideological and confessional criteria.

$\mathrm{Au}$ XVIIe siècle, on ne peut comprendre la notion de citoyenneté sans la mettre en rapport avec la conception du sujet. Les Anglais du temps avaient conscience d'être à la fois sujets du monarque et membres du common weal, ce réseau de relations, de privilèges et d'obligations qui faisait marcher la société et ses institutions jusqu'au niveau le plus local de la paroisse ou du manoir.

Ce que révélaient déjà certaines descriptions de la société et des institutions anglaises à la fin du XVIe siècle se voit confirmé dans les crises d'identification collectives des années 1640. Les soldats de l'Armée Nouveau Modèle de Cromwell s'opposent entre eux, et s'opposent à leurs généraux, comme Oliver Cromwell et Henry Ireton, sur la définition du peuple qui doit être représenté au Parlement. Les débats de Putney, à l'automne 1647, manifestent ces incompréhensions réciproques ainsi que les craintes qui les sous-tendent.

Les constitutions du régime cromwellien à partir de 1653 brossent du citoyen actif un portrait économique et religieux de plus en plus précis, excluant de personnes du corps civique pour des raisons de moralité privée ou d'adhésion religieuse, autant que pour des motifs économiques. En élevant le cens électoral et en multipliant les critères de conformité, le régime ne fait que s'isoler de la société.

À la fin des années 1650, le combat des théoriciens républicains, religieux ou séculiers, se concentre sur l'admission à la citoyenneté et sur l'étendue souhaitable du corps civique. Si tous s'accordent sur la nécessité d'un cens électoral, c'est sur la pertinence des critères idéologiques et confessionnels que la polémique s'est développée.

\section{INDEX}

Mots-clés: Angleterre moderne, républicanisme, commonweal, commonwealth, citoyenneté, histoire sociale

Keywords: Early Modern England, republicanism, commonweal, commonwealth, citizenship, Social history

\section{AUTHOR}

\section{LUC BOROT}

Institut de Recherche sur la Renaissance, l'Âge Classique et les Lumières, UMR 5186 (CNRS/

Université Montpellier III-Paul-Valéry) 